\title{
Human Resource Development: Strategies for Sustainable Rural Development
}

\author{
Professor Dr. Abdul Latif \\ Chairman Department of Management Sciences \\ Islamia University Bahawalpur, Pakistan \\ E-mail: drabdullatif@hotmail.com \\ Muhammad Suhail Nazar \\ Assistant Professor, Deptt: of Management Sciences \\ Islamia University, Bahawalpur, Pakistan \\ E-mail: Suhail_nazar@yahoo.com \\ Tariq Mehmood Khan \\ Assistant Professor, IER, University of the Punjab, Lahore, Pakistan
}

Faiz. M. Shaikh

Assistant Professor

SZABAC-Dokri-Larkana, Sindh, Pakistan

E-mail: faizanmy2000@hotmail.com

Received: September 19, $2010 \quad$ Accepted: January 10, $2011 \quad$ doi:10.5539/ass.v7n6p159

\begin{abstract}
This research investigates the Human Resources Development and strategies for the sustainable rural development in Pakistan. The data were collected from 300 respondents from five Districts Dadu, Nawabshah, Shikarpur, Jacobabad and Kashmore by using simple random technique. It was revealed that the HRD policies are not effective in the rural development in rural Sindh. Studies suggest that the success of a small firm depend more upon the policies it adopted than the buoyancy of the market in which it operates. It was further revealed that external influences are less important, than individual factors, particularly the management competencies and the personal attributes to cope with the small business environment. Some individual's successes as entrepreneur when the odds seems stacked against them, whilst other fail when the conditions for success are relatively good. Micro and Macro both strategies should be properly designed to address the problems of rural people.
\end{abstract}

Keywords: Sustainable, Development, HRD

\section{INTRODUCTION}

The concept of human resource development first introduced by Len Nadler at American Society for Training and Development in United States of America in 1969. Since after two decades this concept gaining importance in Pakistan. Len Nadler defines Human Resource Development as an organizational learning experience with a given period of time with the objectives of producing the possibility of performance change. Human Resource Development strives to improve quality, consciousness among individual work force through all its sub-systems. Among the sub-systems, performance appraisal, training and development are given the highest priority as they are directly involved in skill building and development.

After getting freedom from British rule, Pakistan has achieved tremendous progress, in almost every sphere of human life. It may be in Agriculture, Animal husbandry, Horticulture, Defense, Education Science and 
Technology. The living standard of the people has improved significantly. The literacy rate has also increased up to $42 \%$. The infrastructure like Roads, Electricity, Schools, Banks, in villages has been developed to a level of satisfaction.

It is easier to purchase car and other luxury items by any individuals. The more important is the maintaince of car in good working condition. Similar situation of Rural Development in Pakistan. The more important is to maintain the rural infrastructure in good condition. The strategies for rural development have therefore to be developed, so that Pakistan could not only maintain this achievement but also reach higher standards in all aspects of rural development.

\section{Concept of Human Resource Development}

Human Resource Development (HRD) has become major function of Human Resource Management. This effort will entail more than the expenditure of money, it will require radical changes in our system of values in the way we evaluate human resource in their working environment, regardless, of the type of organization and in the way we view the management function itself, regardless of the product or service.

John Ingalls says, the new concept, which can satisfy the above problems is HRD. It enables to foster continuous development of increased human capacity and performance with a competency based management system.

Human beings also have a need to develop themselves professionally. Development of the capabilities keeps them psychologically sound. This development needs to be mentioned in terms of maketing it with organizational requirements. According to Lippitt, HRD system depends on various factors like:

(a) Work itself which generate a higher degree of responsibilities for the employees.

(b) The individual personal and professional growth,

(c) The improved quality output as a result of increased responsibility, and,

(d) Organization as an open system

The HRD System should be such that it should maintain all people involved. It should developed newer and creative qualities in employees. The term HRD has become very popular in last decade and particularly the emerging of international organizations.

Most of the organizations started renaming their training and development department as a Human Resources Development Centre's and some created new departments. Later, some other personnel management functions like performance appraisal, potential appraisal, career planning and development and data storage system are included as sub-systems of Human Resource Development.

\section{Human Resource Development}

UNDP(1991) Defines Human Resource Development as the policies and programs that support and sustain equitable opportunities for continuing acquisition and application of skill, knowledge, attitude and competencies which promote individual autonomy and are mutually beneficial to individual organization, the community of larger environment of which they are part.

Implied in the above conceptualization of Human Resource Development of many facts of development of people included their physical, intellectual, emotional, social, moral, political, spiritual, and other forms of development.

\section{Data Collection Methodology}

The data were collected from 300 respondents from five Districts Dadu, Nawabshah, Shikarpur, Jacobabad and Kashmore by using simple random technique through structural questionnaire.

\section{Strategies for Sustainable Rural Development}

Rural development is the multi-dimensional aspect of rural areas of Pakistan. The Strategies for sustainability will therefore be multi-dimensional. The important dimensions in rural development are:

- Education

- Health

- Women and Child development

- Rural Electrification

- Rural Industries 
- Infrastructure Development

- Rural Financial institutes

- Rural marketing

- Co-operative societies

- Land Based Programs

Agriculture

Animal Husbandry

Horticulture

Social Forestry

Soil and Water Management

Human Resource Management (Singh, 2001) "is the process of taking maximum and quality work from the employees of an organization by developing their skills, abilities, capacities through training other important method approaches.

\section{HRD AT MACRO AND MICRO LEVEL}

Human Resource Development as started earlier, mainly concern development in people. When we call it as people-oriented concept, the questions should like be the people, be developed in the larger and National context or in institutional context? Is it different at the Micro (institutional) and Macro (National) level issues?

\section{Macro Level}

A Macro level HRD is concerned with the development of the people for the nation's wellbeing's. It deals with the health capabilities, skills and attitude of the people, which are more useful for the development of the Nation While calculating the national income and economic growth perspective HRD concept examines the individual potentialities, their attitude, aspirations, skills knowledge, etc and establishes concrete base for the economic planning and the measures to control inflammation. However, HRD contribution has not been popularized.

\section{Micro Level}

HRD has great concern for gross root development in the organizations. More so it is well received by the management of the companies as they realized its importance and foresaw its future contribution for the individual and organization development. Basically HRD micro level deals with the performance appraisal, potential appraisal, training and development, career planning and organizational development.

There should be effective orientation for the new employees create a positive impact on the performance of the employees.

- Trainings should be provided to the SMEs firms to generate more innovative products.

\section{- Activity For Growth}

- If small firm had the objective of high growth, how would its strategies be different from business with less ambitious growth plans?

\section{- Strategies for growth}

- Small business can be divided into three broad categories for strategic analysis.

- Those likely to cease trading in the near future

- These likely to survive, but which will stay very small

- Those which will not only survive but will also grow rapidly.

- As we have seen, the vast majority of small business falls into the first two categories. Only a tiny minority turn into the high growth enterprises which move quickly towards medium size status and beyond.

- However their significance to the economy is much greater than their numbers imply. High growth firms are those that provide most employment prospects over 30 per cent of the new jobs created by small business are provided by the fasts growing 4 percent of firms. This section looks at some of the influences on their grown.

\section{- The entrepreneur, the firm and strategy}


- In a review of the evidence on small business growth, Storey developed a framework of the characteristics of high growth small firm improving 3 components.

- The starting resources of the entrepreneur

\section{Successful Small Business Strategies}

In this section various influences on the like hood of, first the survival of a new venture and secondly, its growth into larger enterprises has been discussed. These have been divided into external and individual influences and into factors that particularly affect high growth firms. As growth is one of the key factors in survival, many of the influences on survival are similar to those that are important for high growth firms. A composite model of these influences is summarized in critical factors in small business strategies.

Unit 3 (section 5, 'Critical survival factors') summarized the external factors listed above unit 2 (section 6 'Towards successful entrepreneurship') analyzed the building block of successful entrepreneurship which make up the individual factors. This unit has added the important ingredient of motives. Together these factors influence the like hood of success or failure. The overlapping circle indicate the inter dependence of these force. For example the sector in which the firm is set up just as the decision on which sector to start a new venture in is influenced by personal factors and previous experience.

Few entrepreneurs develop a business in which all these factors are favorable disposed. If a complete set of favorable influence is not attainable, which are the most significant ones to get right? Research into successful small firm provides some guidance evidence from several studies suggests that the success of a small firm depend more upon the policies it adopted than the buoyancy of the market in which it operates. External influences are less important; than individual factors, particularly the management competencies and the personal attributes to cope with the small business environment. Some individual's successes an entrepreneur when the odds seems stacked against them, whilst other fail when the conditions for success are relatively good.

\section{CONCLUSION}

The inception and development of information technology in last decade of $20^{\text {th }}$ century has changed the world scenario to great extent. It is so dominating on individual and social life of the people that the marriages are being arranged through internet. The approaches towards Human Resource Development are also changing consequent upon the development of information technology. The scientific innovation are taking place with the faster speed. The common perception might be that the typical small business is more often than not at the emergent end of the spectrum, whilst larger organizations are more deliberate in their strategies process. There is little hard evidence to support this view. Some commentators view entrepreneurial strategy as more toward the intended than the emergent end of the spectrum. The focused control of small enterprise certainly make the process of formulating strategy easier than in large organization. The sheer size and complexity of some enterprises means that changing existing pattern to a deliberate new strategy is a difficult task. In a small business, the owner manger can embark on a new strategy with minimal consultation and communication.

\section{References}

(1990). A Survey of owner managed business Department of Employee, September.

Arya P.P and Tondon, BB. (1998). Human Resource Development. Deep and Deep publication, F-159, Rajouri Garden New Dehli.

Curran J. (1988). The small firm: a neglected area of management in cowling A et, al. Behavioral sciences for Mangers Amole.

Rao TV. (1998). Human Resource Development Sage Publication.

Scott, M and Bruce, R. (1987). Five stages of Growth in small business long range planning, Vol. 20, No. 3.

Singh, Bhavdeep, Kumar, P.C. (1995). Current Trends in Human Resource Development. Sage publication. Singh, R, P. (2000). Management of Training program. Anmol publications, Darya Ganj, New Dehli

The quarterly survey of small business in Britain Small Business Research Trust Open university (2 ${ }^{\text {nd }}$ Q 1989). 